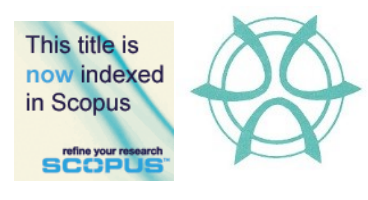

PLANNING MALAYSIA:

Journal of the Malaysian Institute of Planners

VOLUME 19 ISSUE 5 (2021), Page $96-107$

\title{
BEST PRACTICES AMONGST TOUR OPERATORS ON ENVIRONMENTAL MANAGEMENT IN PULAU PAYAR
}

\author{
Mohd Fairus Saad $^{1}$ and Suraiyati Rahman ${ }^{2}$ \\ ${ }^{1,2}$ School of Housing, Building and Planning \\ UNIVERSITI SAINS MALAYSIA
}

\begin{abstract}
A beautiful island, pristine natural environment and abundant marine biodiversity essentially attract segmented tourists to visit marine parks in Malaysia. The marine protected areas (MPAs) in Malaysia are bound to comply with the regulations and guidelines in ensuring the sustainability of the marine ecosystem. However, studies focusing on environmental best practices amongst tour operators in MPAs are limited. Hence, this study attempts to examine environmental management practices amongst the tour operators in Pulau Payar. A qualitative method was adopted using observation and a semi-structured interview with registered tour operators in the designated area. Fifteen respondents participated in the interview. Based on thematic analysis, this study revealed that the tour operators' operating services in Pulau Payar had implemented best practices on environmental approaches using the following: Educate Visitors on Environmental Awareness (1), Using Environmentally Friendly Equipment (2) Conservation Efforts (3) and Waste Management and Amenities (4). In addition, the findings showed that the tour operators play an essential role in educating the tourists and role models to protect the environment.
\end{abstract}

Keywords: Best Practices, Marine Park, Tour Operator, Environmental Management, Tourism Attraction

${ }^{2}$ Suraiyati Rahman. Corresponding Author, Email: suraiyati@usm.my 
PLANNING MALAYSIA

Journal of the Malaysia Institute of Planners (2021)

\section{INTRODUCTION}

The emergence of ecotourism attractions in beautiful islands and protected marine areas had attracted eco-tourists and other segmented tourists. Tourism Malaysia (2020) reported that domestic travellers prefer islands and beach attractions, accounting for $68.6 \%$ of the 12,281 respondents. A marine park that is essentially rich in biodiversity and beautiful coral provides a niche tourism segment market. Establishing a marine protected area (MPA) or marine park is an essential strategy in protecting and maintaining a sustainable ecosystem. MPA is defined as any intertidal or sub-tidal terrain area, together with its overlying water and associated flora, fauna and historical and cultural features, reserved by law or other effective means to protect part of the entire enclosed environment (IUCN, 2009). One of the significant threats in MPA is poor management, which led to degradation of the coastal ecosystem because of untreated water, domestic waste management and waste from tourism activities (Plumpton, 2015). In addition, dive tourism and water sports activities have posed threats to the marine ecosystem caused by anchor damage to the seabed and trampling and touching of coral reefs and marine wildlife (Asian Development Bank, 2014). Conserving the protected areas highly depends on effective environmental management by the stakeholders in the respective areas (Pimid et al., 2020). However, ensuring the sustainability of the ecosystem has many challenges. Internal parties are often those that are directly involved on-site, such as residents, resort and chalet owners, scuba diving operators, and boat service operators(Mohd Nasir et al., 2017). Ultimately, tour operators play an essential role in protecting the natural environment. This study examines the best practices amongst the tour operators on environmental management in their service operation in Pulau Payar.

\section{LITERATURE REVIEW MPAs in Malaysia}

Malaysia has established 53 coral reef MPAs, including 42 coral reef MPAs in Peninsular Malaysia by the Department of Marine Park Malaysia (DMPM). The Department of Marine Park governs all the activities related to coral reefs and tourism activities, whereas the Ministry of Fisheries governs all activities related to fisheries beyond the MPA water area. Fisheries Act 1985 provides the minister's powers to establish any area or part of an area in Malaysian fisheries waters as a marine park or a marine reserve. In addition, section 2(2) of the 1994 order establishes a marine park at two nautical miles seaward from the island's outermost point measured at a low watermark. Sections 43, 44 and 45 of the Fisheries Act 1985 stated that fishing, taking of aquatic animal or aquatic plants, collecting corals, constructing any structure, anchorage of any vessel and destroying any object in the marine parks without any Director-General's prior written permission are an offence (FAO, 1994). The DMPM took the initiative to 
Mohd Fairus Saad and Suraiyati Rahman

Best Practices Amongst Tour Operators on Environmental Management in Pulau Payar

collaborate with the Reef-World Foundation under the United Nations Environment Programme in protecting the coral reefs (Marine Park Department, 2020). The tour operator's operations are subject to the Marine Parks Department designated guidelines, and they are seen as ambassadors to protect and foster a sustainable tourism destination by adopting environmentally friendly guidelines (Marine Park Department, 2020). Mohd Nasir et al. (2017) stated that the key stakeholders' roles should be recognised, and their service delivery should be improved, with the local participation in the management of coastal marine resources.

\section{International Regulation and Codes of Conduct (COCs)}

International Regulation and COCs International Coral Reef Action Network (ICRAN) were established in 2000 under the United Nations Foundation (UNF). 'A Practical Guide of Good Practice' booklet and 'Marine Recreation Checklist' serve as guidance to assist businesses on environmental practices. In addition, the guideline offers the rationale and recommendations for essential practices in mitigating the effects on the marine ecosystem (ICRAN, 2012). Furthermore, UNEP and Reef-World expand the best practices in Asia by establishing a programme known as Green Fins. The programme aims to promote environmentally friendly practices in the marine park for tour operators and visitors, particularly in Asian regions. In addition, the programme allows tour operators to participate in coral reef monitoring, conservation and management (Hunt et al., 2013). The Green Fins programme was initiated in Malaysia in 2008 under the responsibility of the Marine Park Department. Green Fins has provided guidelines for tour operators, and they must strictly follow those guidelines in their daily operations (Marine Park Department, 2020).

\section{Environmental Practices in MPA}

Environmental management emphasises resolving practical issues that arise when humans coexist with nature, resource exploitation and waste production (National Environment Commission, 2011). Environmental management includes enforcing carrying capacity and restricting hazardous activities in protected and zoning areas for specific user activities (J. Day et al., 2019; J. C. Day et al., 2015; Laffoley et al., 2018). As outlined by Orams (1999), management guidelines can be categorised into four strategies: (1) physical, (2) regulatory, (3) economic and (4) education. Physical management strategies include infrastructure for sustainable operation in the coastal area.

The regulation emphasises education management strategies to control any misconduct by human activities in the marine park and encourage voluntary behaviour change. Therefore, educational management strategies provide a beneficial situation for marine park management and tourists (J. C. Day et al., 2015; Laffoley et al., 2018). Hunt et al. (2013) noted that enhanced knowledge 
amongst dive guides, recreational divers and snorkelers is a critical element in ensuring environmental sustainability for diving operations (Dearden et al., 2007; Hasler \& Ott, 2008). Ordoñez and Serrat (2017) stated that the dissemination of information is the distribution of conveying knowledge to intended audiences to effect change. In addition, dive guides play an essential role in advising misconduct behaviour amongst divers to minimise contact on the reef (Hunt et al., 2013; Roche et al., 2016). Regulations and enforcement aim to manage visitors' activities in a destination, specifically in protected areas. For example, in MPAs, respective authorities regulate visitor activities, such as collecting sea life, stepping on corals, fish feeding, littering and fishing within designated areas (J. C. Day et al., 2015; Giglio et al., 2015; Wiener et al., 2009). Amongst other marine activities that may contribute to corals' degradation is the usage of fins by snorkelers. Corals and other reef species are usually damaged by inexperienced snorkelers using fins, tools or body contact (ICRAN, 2012).

One of the approaches is public and private partnerships by promoting best practices in MPA for better sustainable on-site management and operations. For example, the Green Fins programme suggests engaging the dive tourism industry and other related stakeholders to educate, facilitate and improve mutual efforts concerning coral reef sustainability (Hunt et al., 2013). For example, in Hawaii, several public volunteers and paid project activities are available for tourists and tour operators, such as whale monitoring, fish counts, beach cleanups and charitable donations (Wiener, 2009).

Other significant issues in a marine environment that constantly attracted environmental organisations and researchers' attention are solid waste and sewage management (Gerungan \& Chia, 2020; ICRAN, 2012; Lucrezi \& Saayman, 2017). The trash and sewage problem is severe on islands because of a lack of treatment facilities (Dimopoulos et al., 2019; Kossmann, 2015). Gerungan and Chia (2020) posited that the sewage from the pontoon may destroy corals when released directly into the sea. Therefore, sewage disposal must be managed and channel to a certified treatment plant. Furthermore, toilets must not discharge untreated wastewater directly into the sea or freshwater areas or near sensitive regions (ICRAN, 2012; The Foundation for Environmental Education (FEE), 2018).

\section{Background of Pulau Payar}

Pulau Payar Marine Park is approximately 19 nautical miles south of Pulau Langkawi, 32 nautical miles north of Penang and 15 nautical miles west of Kuala Kedah. The Marine Park consists of four islands, namely, Pulau Payar, Pulau Kaca, Pulau Lembu and Pulau Segantang. Pulau Payar has four sandy beaches with nearly $200 \mathrm{~m}$ in length. Pulau Payar gained attention amongst tour operators for scuba diving, snorkelling, swimming and picnic activities because of its beautiful sandy beach and coral reef area. Decent public facilities, such as a 
Mohd Fairus Saad and Suraiyati Rahman

Best Practices Amongst Tour Operators on Environmental Management in Pulau Payar

gazebo, public jetty and toilets, are provided for the visitors. In addition, various dive sites with unique features can be explored by divers, such as Grouper Farm, Japanese Garden, Garden Reefs and Platform Reefs.
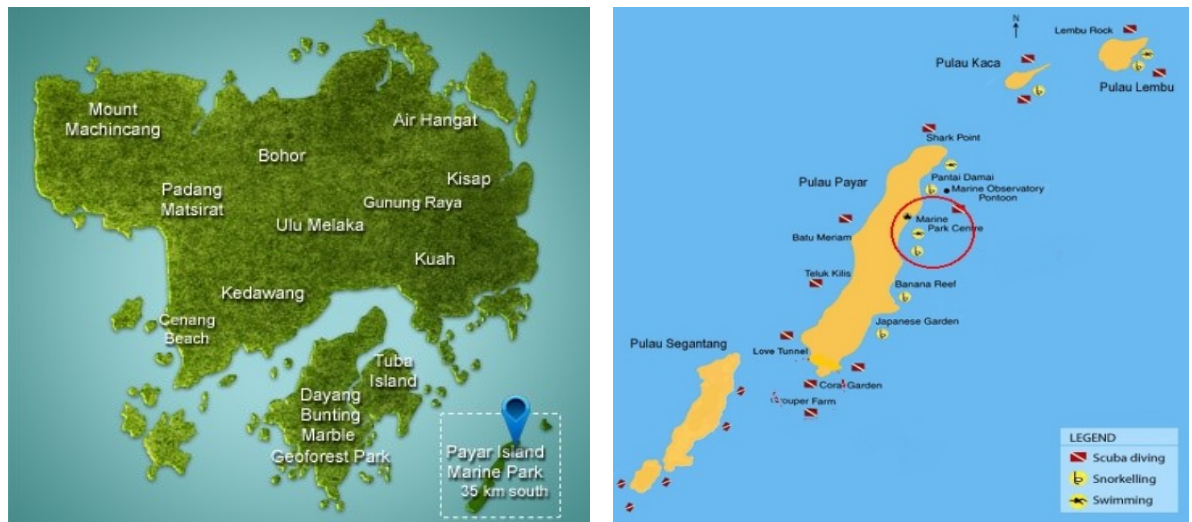

Figure 1 : Location of Marine Park, Pulau Payar, Langkawi Island Source: m.naturallylangkawi.my (2012) \& Marine Park Malaysia Malaysia, (2020)

\section{METHODOLOGY}

This research adopted a qualitative method by using a semi-structured interview is adopted to interview 15 respondents from three tour operators; i. Langkawi Saga and Langkawi Ferry Services; ii. East Marine Holidays; iii. Eko Megah Holidays. This study adopted purposive sampling using the qualitative method. A quota sampling is used in selecting the potential respondent. The criteria for recruiting the respondents are based on those registered with the Marine Parks Department of Malaysia and Green Fins Malaysia. The respondents include officers from Marine Park Department (R1,R2), Operators Managers, Boat Captains, Supervisors, Dive Masters and Customer Service Crews (R3 -R15). The interview questions are developed by adapting works of Wiener (2009), Green Fins (2004) and ICRAN (2012). The data collection was carried out for one month. The case study area is within the Langkawi Coral's platform, beach area, Marine Park centre and two (2) dive sites, namely, Coral Garden and Pulau Kaca. Fifteen respondents agreed to participate in this research. The responses were transcribed and analysed using thematic analysis. All interviews were conducted face to face, which took approximately 45 minutes per session.

\section{RESULT AND DISCUSSION}

OPERATING SERVICE GUIDELINES AND PROCEDURES

Based on the inventory checklist, all the tour operators complied with the regulation except for one tour operator did not showcase the green fin mission statement for public view. Displaying the mission statement for the tourists 
viewing is essential as listed in the best practice's guidelines and inventory checklist by the Green Fins programme. The regulation should be presented in written materials or oral notices. Two tour operators display the mission statement on the pontoon's counter and their ferries, but the Mission Statement size and placement seem to be not strategically for public viewing. Thus, Marine Park Department or Green Fins must clearly outline the mission statement's size that needs to be presented and visible for people to read. The only measure that all tour operators did not abide is distribute environmental awareness written materials, such as brochures or flyers. However, the tour operator had provided oral communication in educating the tourists. According to the ICRAN (2012), anchors for mooring commercial and recreational vessels cause substantial harm to the marine ecosystem. As shown in Table 1 (No. 5), the result shows that all tour operators complied with the guidelines using the mooring buoys and drifting techniques in their operations. Furthermore, all tour operators' boats drop off their divers at the dive location using the drifting technique whilst waiting for each diver turn. Thus, this observation shows that the tour operators comply with the guidelines provided by using designated buoys, drifting techniques and pontoon installations that will adequately protect coral reefs and other aquatic life.

Table 1: Marine Tour Operators Inventory (COC)

\begin{tabular}{|c|l|c|c|c|c|c|c|}
\hline \multirow{2}{*}{ NO } & \multicolumn{1}{|c|}{ ITEMS } & \multicolumn{2}{c|}{ Operator 1 } & \multicolumn{2}{c|}{ Operator 2 } & \multicolumn{2}{c|}{ Operator 3 } \\
\hline & & YES & NO & YES & NO & YES & NO \\
\hline 1 & $\begin{array}{l}\text { Adopt the GREEN FINS mission } \\
\text { statement }\end{array}$ & $/$ & & $/$ & & & $/$ \\
\hline 2 & $\begin{array}{l}\text { Display the GREEN FINS } \\
\text { agreement for public view. }\end{array}$ & $/$ & & $/$ & & & $/$ \\
\hline 3 & $\begin{array}{l}\text { Practice and promote the best } \\
\text { practices diving and snorkelling and } \\
\text { act as responsible role models for } \\
\text { guests }\end{array}$ & $/$ & & $/$ & & $/$ & \\
\hline 4 & Onboard toilets & $/$ & & $/$ & & $/$ & \\
\hline 5 & $\begin{array}{l}\text { Actively use moorings, drift or } \\
\text { hand place anchors for boats }\end{array}$ & $/$ & & $/$ & & $/$ & \\
\hline 6 & $\begin{array}{l}\text { Prohibit the sale or display of } \\
\text { corals, shells and other marine life }\end{array}$ & $/$ & & $/$ & & $/$ & \\
\hline 7 & $\begin{array}{l}\text { Provide adequate trash facilities } \\
\text { onboard your vessel and dispose of } \\
\text { all waste responsibly }\end{array}$ & $/$ & & $/$ & & $/$ & \\
\hline 8 & $\begin{array}{l}\text { Operate under a 'minimum } \\
\text { discharge' policy }\end{array}$ & $/$ & & $/$ & & $/$ & \\
\hline 9 & $\begin{array}{l}\text { Abide by all local, regional, } \\
\text { national and international }\end{array}$ & $/$ & & $/$ & & $/$ & \\
\hline
\end{tabular}


Mohd Fairus Saad and Suraiyati Rahman

Best Practices Amongst Tour Operators on Environmental Management in Pulau Payar

\begin{tabular}{|c|c|c|c|c|c|c|c|}
\hline & $\begin{array}{l}\text { environmental laws, regulations and } \\
\text { customs }\end{array}$ & & & & & & \\
\hline 10 & No to fish feeding & l & & I & & I & \\
\hline 11 & $\begin{array}{l}\text { Provide life jacket whilst } \\
\text { snorkelling }\end{array}$ & / & & I & & / & \\
\hline 12 & $\begin{array}{l}\text { Explaining to guests the best } \\
\text { practices in pre-dive briefings }\end{array}$ & l & & / & & / & \\
\hline 13 & $\begin{array}{l}\text { Provide training, briefings, talks or } \\
\text { information to help employees and } \\
\text { guests understand good } \\
\text { environmental practices for marine } \\
\text { tourism activities }\end{array}$ & / & & / & & / & \\
\hline 14 & $\begin{array}{l}\text { Provide environmental materials } \\
\text { (e.g. ID books, educational posters) } \\
\text { for the staff and guests to read }\end{array}$ & & / & & / & & I \\
\hline 15 & $\begin{array}{l}\text { Promote strict 'NO TOUCH' policy } \\
\text { for all diving and snorkelling } \\
\text { activities }\end{array}$ & / & & I & & / & \\
\hline
\end{tabular}

Based on the semi-structured interview, the tour operators had adopted Educate Visitors on Environmental Awareness (1), Using Environmentally Friendly Equipment (2) Conservation Efforts (3) and Waste Management and Amenities (4). The themes and codes were extracted based on the responses from the interviews.

\section{THEME 1: Educate Visitors on Environmental Awareness}

\section{Code 1: Briefing on Environmental Awareness}

The operators should practice and encourage environmentally friendly diving and snorkelling practices. Previous research revealed that pre-dive briefing is one of the environmental managements that significantly reduces damage in corals (Hunt et al., 2013; Mendes, 2008). During the observation, all the tour operators implemented best practices in a pre-briefing on environmental awareness. The contents of the pre-briefing are also relatively consistent to all tour operators. The briefing focused on COCs in the protected areas, no-touch policy, no-fish feeding, and others related to environmental awareness. Pre-briefing will create awareness and eventually leads the tourists to be more responsible to engage in marine activities. The tour operators' crews (R5, R8 \& R15) conducted their briefing on environmental awareness, such as discouraging the selling and buying of shells and other aquatic species and touching and stepping corals. The crews will provide oral guidance to tourists if they violate the rules in ensuring that tourists adhere to the COC. A tour operator manager (R3) states that 'tourists want the guidance; they feel self-conscious about destroying the reef, but do not know how to avoid bad behavior unless they are told'. Constant observation and reprimands 
by the crews will ensure that tourists adhere to the guidelines throughout the activity. Information dissemination is the collaborative process of conveying knowledge to intended audiences to effect changes and create awareness in protected areas (Ordoñez \& Serrat, 2017). Wiener (2009) mentioned that a few companies offered pamphlets, photo identification books or other materials onboard the boats for the tourist to read to have initial ideas on the dos and don'ts of activities engaged in the marine environment.

\section{Code 2: Audio Visual Tool in Delivering Information of Environment Importance}

The tour operators did not provide any printed materials, such as fish identification manuals and pamphlets for the crew members and visitors reading resources to equip them with essential knowledge on the environmental best practices. For example, the interpretation of the COCs in the Marine Park, which are generally practised onboard and during pre-activity briefings, was seen on audio-visuals. Therefore, the approach that they used is more towards audiovisual, which is more sustainable friendly. The divemaster or crew provides images or videos of the dive site and any marine animals they could encounter and remind them to abide by the best environmentally friendly diving. According to $\mathrm{R} 15$, "We only remind the tourists and staff regarding the impact and prohibition of human contact with marine environment during the briefing session. No printed material available."

\section{THEME 2: ENVIRONMENTALLY FRIENDLY EQUIPMENT}

Code 1: Prohibiting non friendly equipment

Corals and other reef species are frequently crushed and broken by irresponsible or inexperienced snorkelers using fins, tools and body parts (ICRAN, 2012). Hence, flippers (fins) are not allowed to be used inside the marine park, according to the Green Fins' COC. According to R1, before prohibiting using flippers in the marine park, most snorkelers were damaging the corals because they were inexperienced, except for divers. Both operators were observed adhering to the law by prohibiting snorkelers from wearing flippers, except for the diving activity.

\section{THEME 3: CONSERVATION EFFORTS}

\section{Code 1: Conservation Programme}

One of the approaches Green Fins seeks is to engage the dive tourism industry and other related local stakeholders to educate, facilitate and improve mutual efforts concerning coral reef sustainability (Hunt et al., 2013). One of the COCs listed is the participation of tour operators in beach and underwater clean-up events. Thus, from interview sessions with several crew members (R3, R7, R8, R9, R14 \& R10), the researcher discovered that the three tour operators were 
Mohd Fairus Saad and Suraiyati Rahman

Best Practices Amongst Tour Operators on Environmental Management in Pulau Payar

engaged in several conservation programmes, including beach and coral reef cleaning, such as restoration, beach and reef cleaning programmes on Pulau Payar.

\section{Code 2: Demonstrate as a role model}

Demonstrating essential behaviour during the diving activity by a dive guide could further decrease reef contacts by other divers (Hammerton, 2017; Roche et al., 2016). Thus, during the diving session, the divemaster made an effort to pick up waste, such as plastic and snorkel tubes from the underwaters. During study at the site, the researcher noticed that one of the operator's crew members had taken the initiative to clean up floating garbage and solid waste, such as disposable bottles, on the shore and in the water, demonstrating that the crews serve as responsible role models for the visitors. R13 mentioned that, "Everyone in the operations as well tourists have not seen selling or buying of any marine life during their stay at Payar Island."

\section{THEME 4: WASTE MANAGEMENT AND AMENITIES} Code 1: Waste Management System on Vessel and Designated Area

According to Gerungan and Chia, (2020) and ICRAN (2012), the trash in the ocean can entangle, entrap and be consumed by marine animals and destroys coral colonies. Based on the observation at the study site, the researcher has identified that the garbage facilities are available on the pontoon and the main beach areas. According to R1 from Marine Park Department, an incinerator is applied to the disposal of biodegradable solid waste on individual islands, which can be easily disposed of by combustion or through high-heat methods. However, because of the high maintenance cost, the incinerator was no longer in service. According to R3, the collected rubbish was kept in waste bags and disposed of at designated areas on the mainland. The responsible practice in managing the waste revealed that tour operators and the Marine Park Department have provided adequate facilities and taken initiatives to guide tourists to maintain the cleanliness of marine park areas. In the ferry facility, they are using type three (III) marine sanitation systems, and typically, a storage tank stores waste until it is disposable at sea or the shore side (beyond three (3) miles from shore).

\section{Code 2: Amenities at Designated Area}

Human wastes contain nutrients, parasites and viruses that may lead to disease and algal bloom in the marine ecosystem of the near-shore areas (ICRAN, 2012). Toilet facilities are available on each tour operators' ferries equipped with sewage holding systems in the observation. According to the Marine Department of Malaysia, sewage on each ferry will be discharged according to regulations as follows: 'the discharge of sewage into the sea is prohibited, except when: the ship is discharging communicated and disinfected sewage at more than three nautical 
miles from the nearest land. The same approach adopted in MPA in ensuring sewage which is not disinfected at more than twelve nautical miles from the nearest land, the sewage that has been stored in holding tanks shall not be discharged instantaneously, but a moderate rate when the ship is en route at not less than 4 knots; the rate of discharge shall be approved by the Director of Marine. The Department of Marine Parks provides a public toilet located on the main beach, but the water supply is minimal. Toilets are typically attached to a waste management plant that can substantially limit untreated sewage or wastewater drainage at sea. The toilets are attached to Individual Septic Tanks in Pulau Payar and connected to the main sewage treatment plant. The residual 'sludge' will be pumped out for a specific time by a designated vessel to transport the sewage, usually every two to five years.

\section{CONCLUSION}

In conclusion, the tour operators are fully aware of environmental practices and COCs. The findings showed that the tour operators play an essential role in educating the tourists and acting as role models to protect the environment. The roles of tour operators are essential in ensuring the implementation of $\mathrm{COC}$ as they deal directly with visitors and the marine environment. As shown in this study, tour operators adhere to the COC responsibly and comply with International and Malaysian regulations in sustaining the environment. However, some tour operators are not aware of the importance of the mission statement and agreement that may increase the awareness amongst the tourists. Collaboration and partnership amongst key stakeholders, namely, Marine Park Department, Fisheries Department, tour operators and visitors, will benefit the sustainability of the environment and resources for the tourism industry.

\section{ACKNOWLEDGEMENTS}

The authors would also like to extend the deepest gratitude to the Malaysia Marine Parks Department in Putrajaya for granting the permit to conduct the research, the Marine Parks Department in Kedah and all respondents for their cooperation. The author(s) would like to extend their appreciation to the Univeristi Sains Malaysia for granting the RUI Grant entitled The Impact of Sharing Economy (AIRBNB) Towards Resident's Quality of Life in High Rise Dwellings (Grant No. 203.PPBGN.8016110) that makes this publication possible.

\section{REFERENCES}

Asian Development Bank. (2014). State of The Coral Triangle: Malaysia. In Asian Development Bank.

Day, J. C., Laffoley, D., \& Zischka, K. (2015). Marine protected area management. In Protected Area Governance and Management. 
Mohd Fairus Saad and Suraiyati Rahman

Best Practices Amongst Tour Operators on Environmental Management in Pulau Payar

Day, J., Dudley, N., Hockings, M., Holmes, G., Laffoley, D., Stolton, S., Wells, S., \& Wenzel, L. (2019). Guidelines for applying the IUCN protected area management categories to marine protected areas Second edition. In Best Practice Protected Area Guidelines Series (Issue 19).

Dearden, P., Bennett, M., \& Rollins, R. (2007). Perceptions of diving impacts and implications for reef conservation. Coastal Management, 35, 305-317.

Dimopoulos, D., Queiros, D., \& van Zyl, C. (2019). Sinking deeper: The most significant risks impacting the dive tourism industry in the East African Marine Ecoregion. Ocean and Coastal Management, 181(January), 104897.

FAO. 1994. "Establishment of Marine Parks Malaysia Order 1994." Food and Agriculture Organization of the United Nations. Retrieved January 20, 2021

Gerungan, A., \& Chia, K. W. (2020). Scuba diving operators' perspective of scuba diving tourism business in Nusa Penida, Indonesia. Journal of Outdoor Recreation and Tourism, 31(September), 100328.

Giglio, V. J., Luiz, O. J., \& Schiavetti, A. (2015). Marine life preferences and perceptions among recreational divers in Brazilian coral reefs. Tourism Management, 51, 4957.

Green Fins. (2004). The Green Fins Code of Conduct. United Nation Environmental Program (UNEP).

Hasler, H., \& Ott, J. (2008). Diving down the reefs? Intensive diving tourism threatens the reefs of the northern Red Sea. Mar. Poll. Bull., 56, 1788-1794.

Hunt, C. V., Harvey, J. J., Miller, A., Johnson, V., \& Phongsuwan, N. (2013). The Green Fins approach for monitoring and promoting environmentally sustainable scuba diving operations in South East Asia. Ocean and Coastal Management, 78, 3544.

ICRAN. (2012). A practical guide to good practice: managing environmental impacts in the marine recreation sector. International Coral Reef Action Network.

IUCN. (2009). WCPA Marine Plan of Action. Retrieved January 20, 2021, from http://www.iucn.org/about/union/commissions/wcpa/wcpa what/wcpa marine/w cpa_marineaction

Laffoley, D., Baxter, J. M., Day, J. C., Wenzel, L., Bueno, P., \& Zischka, K. (2018). Marine protected areas. World Seas: An Environmental Evaluation Volume III: Ecological Issues and Environmental Impacts, January, 549-569.

Lucrezi, S., \& Saayman, M. (2017). Sustainable scuba diving tourism and resource use: Perspectives and experiences of operators in Mozambique and Italy. Journal of Cleaner Production.

Marine Park Department. (2020). History of Establishment. Retrieved February 23, 2021, from Department of Marine Park Malaysia: http://www.dmpm.nre.gov.my/

Nasir, N.M., Mansor Ibrahim, L.H.M., Othman, R., Challenges to Implement Carrying Capacity Framework: A Case Study of Pulau Perhentian Marine Park Institutional Framework (2017) Journal of the Malaysian Institute of Planners, 15 (1), pp. 163 168

National Environment Commission. (2011). Environmental management tools \& techniques - National Capacity Self Assessment Project. National Environment Commission Secretariat Royal Government of Bhutan.

Orams, M. (1999). Marine Tourism Development impacts and management. Routledge. 
Ordoñez, M., \& Serrat, O. (2017). Knowledge Solutions: Tools, Methods, and Approaches to Drive Organisational Performance. In Knowledge Solutions: Tools, Methods, and Approaches to Drive Organisational Performance (pp. 871-878). Asian Development Bank.

Pimid, M., Latip, N. A., Marzuki, A., Umar, M. U., \& Krishnan, K. T. (2020). Stakeholder management of conservation in lower Kinabatangan Sabah. Planning Malaysia, 18(3), 71-81.

Plumpton, R. (2015). Nature-based Marine Tourism in the Coral Triangle: exploring the potential for low-impact, high-value nature-based marine and coastal tourism. December, 196.

Roche, R. C., Harvey, C. V., Harvey, J. J., Kavanagh, A. P., McDonald, M., SteinRostaing, V. R., \& Turner, J. R. (2016). Recreational Diving Impacts on Coral Reefs and the Adoption of Environmentally Responsible Practices within the SCUBA Diving Industry. Environmental Management, 58(1), 107-116. h

The Foundation for Environmental Education (FEE). (2018). Blue Flag Sustainable Boating Tourism Operator Criteria and Explanatory Notes.

Tourism Malaysia. 2020. "Survey on Domestic Travel in Malaysia After Movement Control Order (MCO)." (April):8.

Wiener, C. S., Needham, M. D., \& Wilkinson, P. F. (2009). Hawaii's real-life marine park: Interpretation and impacts of commercial marine tourism in the Hawaiian Islands. Current Issues in Tourism, 12(5-6), 489-504.

Received: $5^{\text {th }}$ November 2021. Accepted: $5^{\text {th }}$ December 2021 